\title{
マイクロ波方式による転炬内溶銑レベル計 "
} の開発

IIIIIIIIIIIIIIIIIIIIII!

\author{
川田豊* ·真鍋知多佳* · 小林 明* \\ 坪根 踇*2.山名 寿*2
}

\section{Development of a Level Meter for Molten Iron in a Converter Using Microwave}

Yutaka Kawata, Chitaka Manabe, Akira Kobayashi, Iwao TuBOnE and Hisashi YamanA

\section{Synopsis :}

A precision microwave level meter based on frequency moduration (FM) method has been developed for measuring the molten iron level in a converter. In order to attain as high accuracy as $20 \mathrm{~mm}$ in the measurement range of $20 \mathrm{~m}$, new technique has been developed for improving the $\mathrm{SN}$ ratio of the received signal and decreasing the quantized error of the conventional FM method.

The initial phase of the received signal caused by the reflection wave from the surface of molten iron always fluctuates as a result of fluctuation of its level. By averaging the waveform of the received signal, the noise component caused by fixed targets such as an antenna cover is extracted. Thus the SN ratio of the received signal is improved by subtracting the averaged waveform of the received signal from the instantaneous one.

In order to decrease the quantized error, modulation is applied to the phase fraction of the noise-cancelled signal. During one cycle of the phase moduration, the zerocrossing counts of the signal are averaged, and so the quantized error is reduced.

These level meters were installed to converters in Kakogawa Works of Kobe Steel, Ltd. and contribute effectively to improving the hitting ratio of blowing.

Key words : converter; blowing control; hitting ratio; level measurement; molten steel ; microwave sensor; frequency modulation; phase modulation.

\section{1. 緒}

\section{言}

転灯操業では，吹鍊の的中率の向上を図るうえで，溶 銑のレベルを正確に測定し，吹鍊用ランスと湯面との間 隔，ならびにサブランスの浸漬深さを最適值に制御する ことが重要である．湯面レベルの測定方法としては，サ ブランス先端に設けた電極を湯面上におろし，溶銑によ り導通したときのサブランス降下位置より求める方法が 一般的である1). しかし，底吹き擋拌による湯面変動の ため測定值のばらつきが大きいこと, 測定時間が長いこ と，および電極が消耗式であることなど問題点が多く, 非接触式かつ精度の高いレベル計が望まれていた。

非接触で湯面レベルを測定する方法としては，レー
ザーや超音波を用いる方法が考えられる.レーザー測距 計は炉内のダストによる散乱減衰が大きいために，十分 な強度の反射信号が得られない. さらに, 高温・高粉塵 の測定環境での光学系の耐久性に不安が残る. 超音波法 は装置構成が簡便なことが魅力的であるが, 炬内の温度 変化に伴う音速変動のため高精度の測定は期待できな い. 一方, 波長が $10 \mathrm{~mm}$ 程度のマイクロ波は, ダスト による散乱減衰を受けにくいうえに, 伝播速度の温度変 動が無視できるので, 悪環境下での非接触レベル測定に 適している.

湯面レベル計として要求される測定精度は約 $20 \mathrm{~mm}$ である.また測定装置を吹鍊中の火炎から守るためには, 湯面上 $20 \mathrm{~m}$ 程度の距離に設置する必要があり, 測定レ

平成 2 年 3 月 12 日受付 (Received Mar. 12, 1990)

* (株)神户製鋼所電子技術研究所 (Electronics Research Laboratory, Kobe Steel, Ltd., 1-5-5 Takatsukadai Nishi-ku Kobe 651-22)

*2 (株)神戸製鋼所加古川製鉄所（Kakogawa Works, Kobe Steel, Ltd.) 


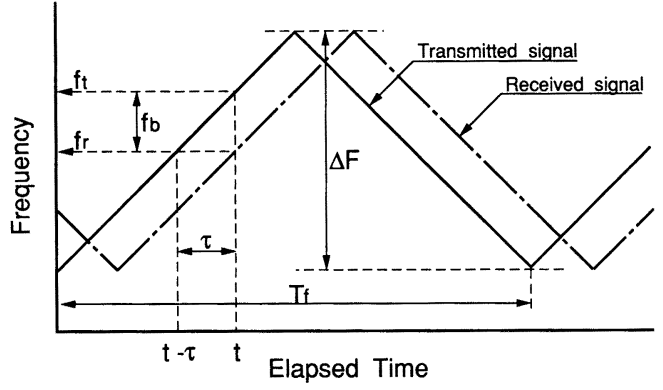

Fig. 1. Principle of FM radar.

ンジに対して $0.1 \%$ の高い相対精度が要求される. マイ クロ波による測距方法としてはパルスレーダーと FM (周波数変調) レーダーが代表的である. パルスレーダー は，パルス波を送信し反射波の遅れ時間から距離を測定 するもので，長距離測定に適しているが，上記精度を達 成するのは困難である．一方 FM レーダーは，航空機 の着陸時の高度計など近距離の測定に適している．FM レーダーでは，周波数変調したマイクロ波を測定対象に 放射し, 受信波と送信波の周波数差から距離を算出する.

Fig. 1 に送信波の周波数を三角波状に変調した場合の 周波数の時間変化を示す. 対象物で反射された後，受信 されるマイクロ波は, 対象物ーアンテナ間を伝播する時 間 $\tau$ だけ時間軸方向にずれるので，送受信波の周波数 には $f_{b}$ だけ差が生じる. 変調幅を $\Delta F$, 変調周期を $T_{f}$ とすると Fig. 1 より以下の関係が導かれる.

$$
f_{b}=\left(2 \Delta F / T_{f}\right) \cdot \tau
$$

光速を $c$, 測定距離を $d$ とすると, $\tau=2 d / c$ なので

$$
d=\left(c T_{f} / 4 \Delta F\right) \cdot f_{b}
$$

反射波と送信波を混合検波すると，両者のうなりに相 当するビート波が得られる. ビート波は周波数差 $f_{b}$ に 等しい周波数をもつので，その周波数を測定し( 2 )式に 代入すると距離が算出できる.

FM レーダーを工業計測に応用した例としては，高炉 内の装入物分布測定位置や ${ }^{2)}$, トーピードカー内の溶銑 レベル計 ${ }^{3)}$ 等が報告されている.これらの報告例では， 測定精度は測定レンジに対して $0.5 \%$ 程度であるが, 転 炉内レベル計の場合は $0.1 \%$ のさらに高い相対精度が要 求される.そこで，FM レーダー方式に基づいて，転炉 内レベル計を開発するためには，以下に示すさまざまな 技術課題を解決する必要がある.

1 )微弱な受信信号から正確な距離情報を抽出するた めの, 不要反射成分の除去

2 )FM レーダーに固有の誤差であるステップ誤差の 軽減
3 ) ドリフト要因を除去するための自動較正法の確立 4 ) ダストや高温雲囲気から測定装置を保護する方法 今回，これら技術課題を解決して溶銑レベル計を開発 し，(株)神戸製鋼所・加古川製鉄所の全転炉に適用した。 本報告では，上記課題の解決法と開発したレベル計の 構成および実操業への活用方法についてのべる.

\section{2. 転炉溶銑レベル計の基本設計}

高粉塵の環境下でマイクロ波を伝播される場合, 波長 を粉塵の粒径に対して 1 桁以上大きくすれば，散乱によ る減衰は許容しうるレベルになる，転炉から吹き上げら れるダストの粒径は高々 $1 \mathrm{~mm}$ 程度である.したがって， マイクロ波の波長は $10 \mathrm{~mm}$ 以上とすべきである.

一方, 波長 $\lambda$, アンテナの口径 $D$, マイクロ波の主ビー 厶の半值幅 $\theta$ の関係は, $\theta_{[\mathrm{rad}]} \sim \lambda / D$ で与えられる. 20 $\mathrm{m}$ の測定距離に対して, 主ビームの拡がりを直径 $1 \mathrm{~m}$ 以下とするためには， $\theta$ は $2.8^{\circ}$ 以下にすべきである. アンテナの直径としては, 転炉上方に設ける観測孔の大 きさ，保全の容易さ等を考慮すると， $40 \mathrm{~cm}$ 以下とした い.これらの条件から, マイクロ波の中心周波数は 24 $\mathrm{GHz}(\lambda=12.5 \mathrm{~mm})$ とし, 直径 $40 \mathrm{~cm}$ のパラボラアン テナを採用することとした。

マイクロ波の発振源としては, 小型で耐久性の高いこ とからガンダイオードが最適であるが, $24 \mathrm{GHz}$ 帯では 出力電力は数十 $\mathrm{mW}$ 程度しか得られない. 発振出力 $P_{t}$ $=10 \mathrm{~mW}$, 測定距離 $d=20 \mathrm{~m}$, 溶銑表面の反射率 $R$, 溶銑表面上でのビームの拡がり面積 $\sigma=0.55 \mathrm{~m}^{2}$, アン テナのゲイン $G=36.5 \mathrm{~dB}$ とすると, 溶銑で反射され た後受信される電力 $P_{r}$ は4)

$$
P_{r}=\frac{P_{t} G^{2} \lambda^{2} \sigma}{(4 \pi)^{3} d^{4}} \cdot R=R \times 55 \quad \mathrm{nW}
$$

マイクロ波受信用の検波ダイオードの等価雑音電力は $0.1 \mathrm{nW}$ 以下なので, 湯面の反射率が 0.1 程度しかない としても，十分検出可能である，以上をまとめ，今回開 発した溶銑レベル計の基本仕様を Table 1 に示す.

\section{FM レーダーの高精度化技術}

\section{$3 \cdot 1$ 不要反射波の除去技術}

前章で述べたように, 受信されるマイクロ波の電力は

Table 1. Specifications of level meter.

\begin{tabular}{cc}
\hline Center frequency of microwave & $24.1 \mathrm{GHz}$ \\
Microwave power & $10 \mathrm{~mW}$ \\
Diameter of antenna & $400 \mathrm{~mm}$ \\
Antenna gain & $36.5 \mathrm{~dB}$ \\
Half-power beam width & $\pm 1.2^{\circ}$ \\
\hline
\end{tabular}


$10 \mathrm{nW}$ オーダーと微弱なうえに，各種不要反射波がノ イズとして重盢する．アンテナおよびダスト防止用カ バーからの反射波は，最大限に整合をとったとしても， 数 $\mu \mathrm{W}$ 程度は残る。ささらに，アンテナから放射される マイクロ波ビームには，主ビーム以外に放射角度の大き い所にもサイドローブとよばれる放射波が必ず存在し， 測定孔内や炉口からの反射波は避けがたい. 今回開発し たアンテナでは，指向角度 $\pm 4^{\circ}$ ，付近に主ビームに対 して約 1\% (-20 dB) の強度のサイドローブが存在し, 測定孔内に地金が付着した場合など強い反射波を生じさ せる.

Fig. 2 は実炉実験で得られたビート波を周波数解析し た例である.ビート波の周波数は反射点とアンテナ間の 距離に比例するので, 同図の横軸は反射点までの距離を

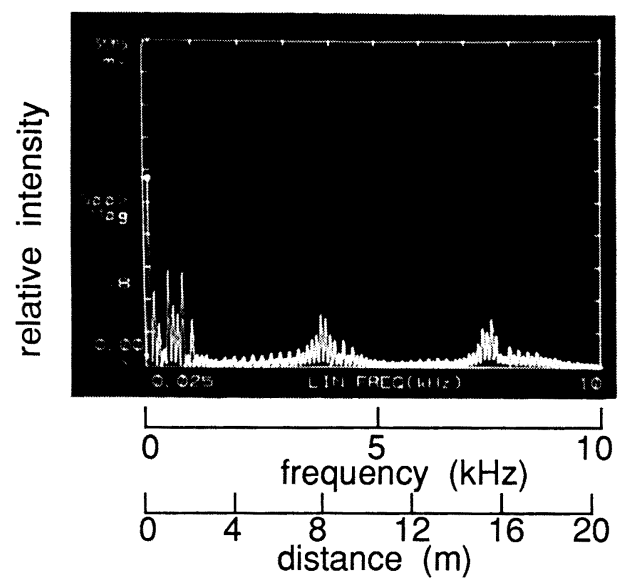

Fig. 2. Frequency spectrum of beat signal.
示している. 最も近距離の周波数成分は, アンテナや測 定孔壁からの反射であり, 距離 $8 \mathrm{~m}$ 付近の成分は炉口 からの反射波によるものである. 距離 $16 \mathrm{~m}$ 付近の成分 が湯面からの反射によるもので，その強度は不要反射成 分より小さい. 信号と不要反射成分の比を SN 比と定 義すると，本レベル計の $\mathrm{SN}$ 比はおおむね $0.1 \sim 0.2$ で ある。

ノイズ成分の除去方法としては，周波数フィルターを 用いるのが簡便であるが, 周波数変調のため信号とノイ ズの周波数帯域が重なっており，完全に分離できない. そこで，ノイズ成分は固定物からの反射波に起因するた め位相は変化しないが，湯面からの反射波はバブリング による湯面変動のため, 位相が常に変化していることを 利用して，ノイズを除去する方法を考案した.

ノイズの除去回路のブロック図を Fig. 3 に示す. 同 図において，まず測定開始信号を受けるとスイッチは $\mathrm{B}$ 接点側に接続され, 加算器と波形メモリを用いて, ビート波の 1 変調周期ごとの波形を加算していく．－一方 FM 三角波の数をカウンターで計数し, 計数值が初期加 算回数 $N$ に達した時点でスイッチが $\mathrm{A}$ 接点側に切り変 わり, ノーマライザー A を介して加算器に接続される. ノーマライザー A で, $N$ 回分の加算波形に $(N-1) / N$ の係数を乗じたのち, 加算器で新たな 1 波形を加えるこ とにより，波形メモリには $N$ 回分の加算波形が，FM の 1 周期ごとに更新されながら保持される.

ノーマライザー B は $1 /(N-1)$ の係数を乗算する機 能を持っているので, その出力は過去 $N$ 回分のビート 波形の平均値となる. ビート信号のうち，固定物からの 反射に起因する成分は位相が一定なので, 平均回数にか

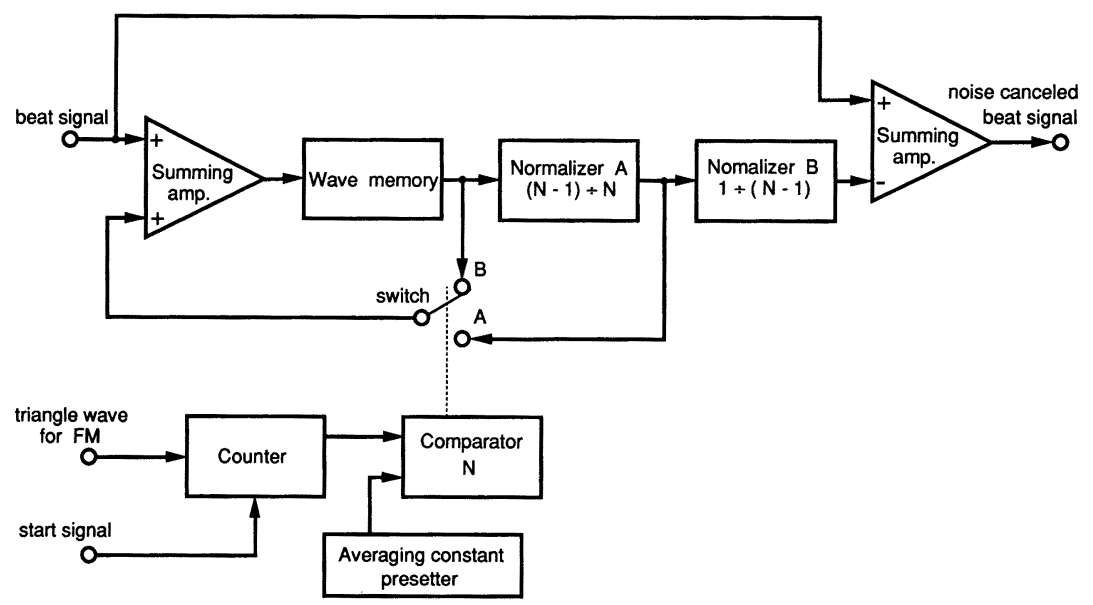

Fig. 3. Block diagram of noise canceler. 
かわらず波形は変化しない。一方湯面からの反射に起因 する成分は，湯面変動のため変調周期ごとに位相が変化 するので平均回数が増えるにしたがって振幅が小さくな る. 従って, ノーマライザー B の出力は, ビート信号 の内不要反射成分のみを取り出したものとなるので, ビート信号の原波形と差をとることにより，湯面からの 反射波による成分のみを抽出できる.

Fig. 4 に本手法を用いてビート波の SN 比を改善し た例を示す．同図の上部が元のビート波形であり，下部 がノイズ除去したのち増幅した結果である，不要反射に よる低周波成分がほぼ完全に除去されているのがわか る.

\section{$3 \cdot 2$ ステップ誤差の軽隇方法}

ビート波の周波数を検出する方法としては，ビート波 の零交差点数を計数する方法が最も信頼性が高い. しか しこの方法では, 零交差点の計数值は常に整数なので, ある範囲内で距離が変化しても, 計数值は変化しない場

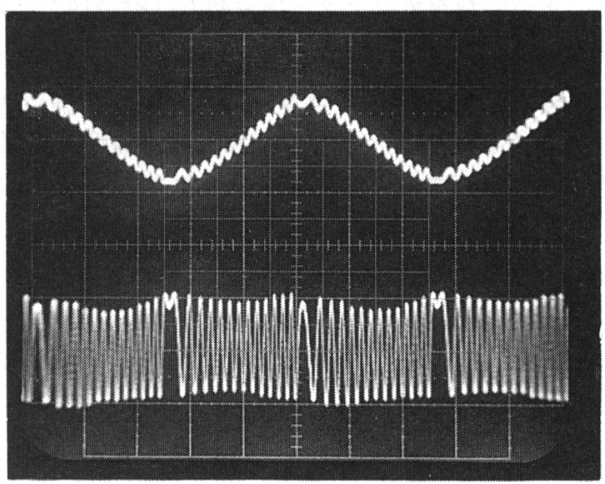

Beat signal (upper) Noise canceled beat signal (lower)

Fig. 4. Improvement of $\mathrm{SN}$ ratio by noise canceler.
合がある。このことによる誤差は，ステップ誤差 $d_{c}$ と 呼ばれ，(4)式で表される5).

$$
d_{c}=c / 4 \Delta F
$$

たとえば, $\Delta F=200 \mathrm{MHz}$ とするとステップ誤差 $d_{c}$ は $375 \mathrm{~mm}$ と大きな值となる， $\Delta F$ をさらに大きくする ことによりステップ誤差は減少するが，マイクロ波回路 を広帯域化する必要があり, 回路の調整が困難になるこ とや，装置の大型化がさけられず実用的ではない．

そこで, $200 \mathrm{MHz}$ 以下の変調幅で $20 \mathrm{~mm}$ の目標精度 を達成する方法として，ビート波に位相変調を加える新 しい方法を考案した。マイクロ波の中心角周波数を $\omega$, 変調周期を $T_{f}$, 変調幅を $\Delta F$ とし, 式を簡単にするた め，正弦波状に周波数変調を加えるものとする。この時 ビート波の電圧は振幅を $A$ として次式で与えられる ${ }^{2)}$.

$$
\begin{aligned}
& E_{b}=A \cos \left(\omega \tau+\gamma \cos \left(2 \pi t / T_{f}\right)\right) \\
& \gamma=\pi \cdot \Delta F \cdot \tau
\end{aligned}
$$

(6)式は， $\gamma$ が伝播遅れ時間 $\tau$ に比例することを示して いる.（5)式において $E_{b}=A \cos \Phi$ とおくと $\Phi=\pi \times$ $(1 / 2$ +整数) となった時にビート波の電圧は零となる. 位相 $\Phi$ は， $\omega \tau$ を中心にして $\pm \gamma$ だけ回転するから， 一変調周期内のビート波の零交差点を計数することによ り $\gamma$ の大きさが $\pi$ の整数倍 $n$ として求まる. しかし零 交差点数 $n$ は初期位相 $\omega \tau$ の大きさによって 1 カウン 卜分だけ不確定となり， $\omega \tau$ が 0 から $\pi$ まで変化する間 に零交差点は $n$ または $n+1$ の值をとる.

そこで, 周波数変調周期 $T_{f}$ より十分大きくかつ整数 倍となる時間 $T_{p}$ を設定し，この間にビート波の初期位 相を $\omega \tau$ から $\omega \tau+2 \pi$ まで変調しながら零交差点数を 積算する．次にこの積算值に $T_{f} / T_{p}$ を乗じて平均する ことにより, 零交差点数 $n$ の小数部が求まるのでステッ プ䛊差が軽減できる. 本レベル計では $T_{f}=1 \mathrm{~ms}, T_{p}=$ $100 \mathrm{~ms}$ とし 100 回分の平均を取ることとした.

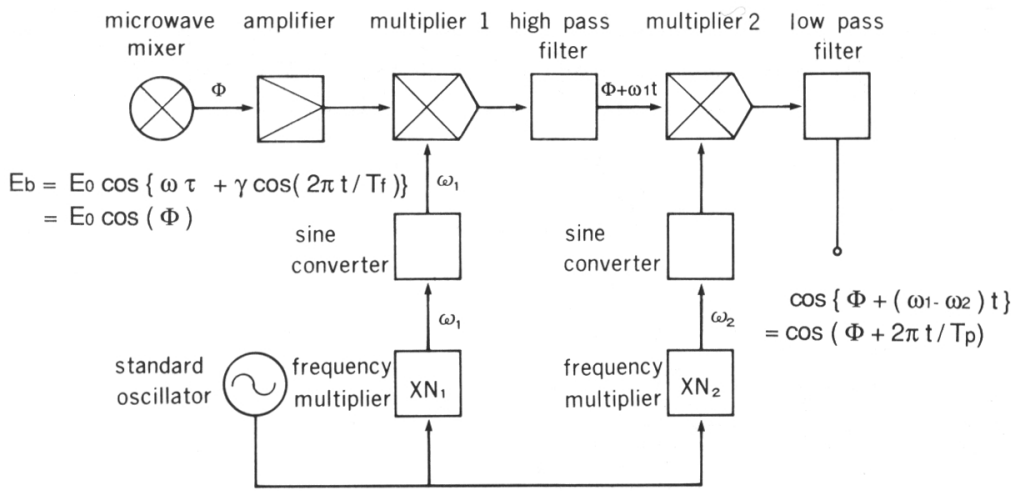

Fig. 5. Block diagram of phase modulation circuit. 
ビート波の位相変調回路を Fig. 5 に示す. 混合検波 器から得られたビート信号 $A \cos \Phi$ を増幅し, 乗算器 で角周波数 $\omega_{1}$ の正弦波を混合したのち，ハイパスフィ ルターで $\cos \left(\Phi+\omega_{1} t\right)$ の成分を取り出す. 次に角周 波数 $\omega_{2}$ の正弦波と乗算したのちローパスフィルターを 通すと $\cos \left(\Phi+\left(\omega_{1}-\omega_{2}\right) t\right)$ の信号が得られる.ここ で, $T_{p}=2 \pi /\left(\omega_{1}-\omega_{2}\right)$ となるように, $\omega_{1}, \omega_{2}$ を選 んで扔くと, ビート波の位相項には $2 \pi t / T_{p}$ の項が加 わったことになる.このことにより, 測定時間 $T_{p}$ の間 に位相を $2 \pi$ だけ直線的にスイープさせることになる.

前節で述べたノイズ除去方法と, 位相変調法を組み合 わせて精度検定を行った結果を Fig. 6 に示す. ビート 信号の SN 比を故意に悪くするために, 測定対象には

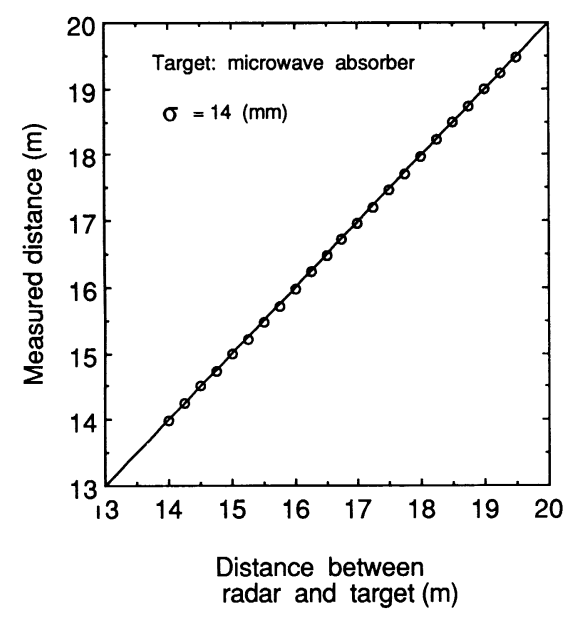

Fig. 6. Measurement result of microwave level meter.
反射率 $1 \%$ のマイクロ波吸収材を用いた。この測定では $\Delta F$ を $200 \mathrm{MHz}$ に設定したので，ステップ誤差は 375 $\mathrm{mm}$ であるが, 直線誤差の標準偏差として $14 \mathrm{~mm}$ の高 い精度が得られ本手法が効果的なことが確認できた。

\section{$3 \cdot 3$ 自動较正方法}

転炬上部の高温䨌囲気中にレーダーユニットを設置す るので, 空冷を施しているが, マイクロ波回路部の温度 変動は避けがたい. 特にガンダイオードは温度により発 振特性が変化するので, 変調幅が初期設定值からずれる ことによる測定值のドリフトが懸念される.

そこで, レーダーユニット内に較正線路を設け, 测定 前に較正線路の反射波によるビート波の周波数を検出し て変調幅を算出する方法を採用した. 較正線路としては, 導波管を用いるとマイクロ波の減衰が最も小さくなる が, $20 \mathrm{~m}$ 長の導波管をレーダー部に収納するのは困難 である．一方同軸線路は柔軟で容易に収納できるが，1 $\mathrm{m}$ あたり約 $2.5 \mathrm{~dB}$ の減衰があるので測定困難である. そこで, 柔軟性があり, かつ減衰も評容範囲内であるセ ミリジッドケーブルを使用し較正線路を製作した. ケー ブルの外径は $3.6 \mathrm{~mm}$ と小さいので, 直径 $8 \mathrm{~cm}$ でコイ ル状に巻いたが, かさばらず, 減衰率も $48 \mathrm{~dB}$ なので 湯面からの信号と同等の SN 比が得られることを確認 した.

\section{4. 溶銑レベル計の装置構成}

加古川製鉄所・転炬工場において設備化した溶銑レベ ル計の装置構成を，Fig. 7 に示す．各転炉ごとに炉口部 上方に設置したレーダーおよび信号処理ユニットと, 電 気室に設置したデータ処理ユニットから構成される.

レーダー・ユニットに内蔵されているマイクロ波回路

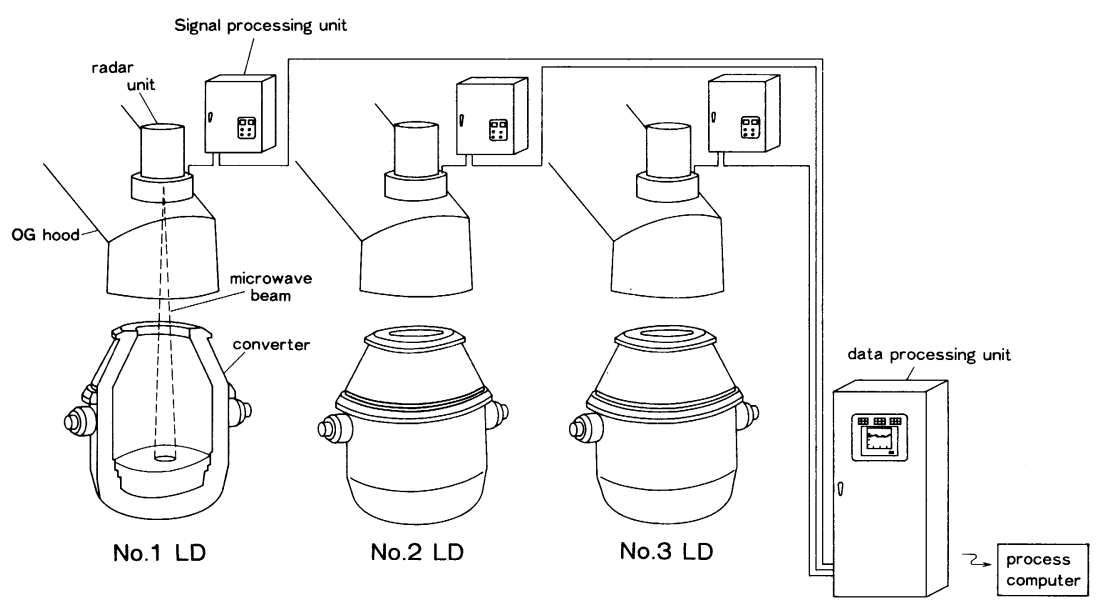

Fig. 7. Schematic diagram of microwave level meter for converter. 


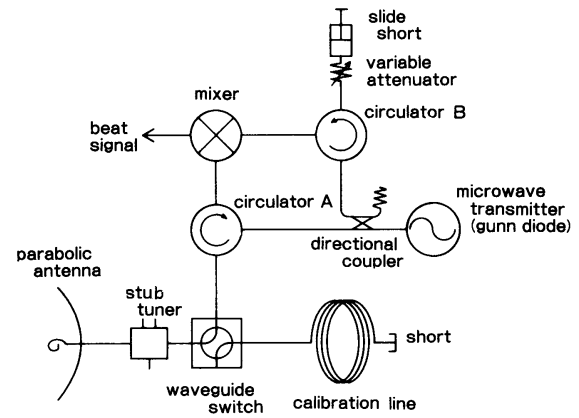

Fig. 8. Block diagram of microwave circuit with calibration line.

の構成を Fig. 8 に示す. ガンダイオードで発振された マイクロ波は, 方向性結合器, サーキュレーター A を 経由してアンテナから湯面に向かって放射される．反射 波は同じアンテナで受信されたのちサーキュレーター $\mathrm{A}$ を介して混合検波器に入力される。一方送信波の一 部は方向性結合器で分岐され，可変短絡器で反射したの ち混合検波器に導かれ，受信波と混合検波されてビート 波を生じる.

レーダー・ユニットは，OG フードに設けた測定孔に 鉛直下向きに設置した. アンテナ前面にマイカ製のカ バーを取り替え容易な構造で設置し，炬内から吹き上げ るダストから保護した．さらに，マイカ板へのダスト付 着を防止するために窒素パージをおこなっている。この 結果一炉代にわたってメンテナンス・フリーで運転可能 となり，炉修ごとの保全もマイカ板のみを引き抜いて付 着したダストを除去するだけである.

Fig. 9 に信号処理ユニットの機能を示す. 混合検波器 から送られてくるビート波をノイズ除去回路に入力し不 要反射波の成分を除いたのち, 位相変調回路に入力する. 位相変調されたビート波はコンパレーターでパルス列に
変換されたのちゲートに入力される. 三角波発信器は, ガンダイオードに周波数変調用のバイアス電圧を出力す る. 同時にカウンターBでその周波数を計数して, 位 相変調周期に相当する時間を検出して測定ゲートを開 き，この間のパルス数をカウンター A で計数する.こ のカウント值はデータ処理ユニットにおいて, 湯面レベ ル値に換算され，その結果はプロセスコンピューターに 送信される.

\section{5. 実炉試験結果}

実炉での試験結果を Fig. 10 に示す．吹錬開始前に測 定した溶鉄レベルおよび，出鋼後の炉底を対象とした測

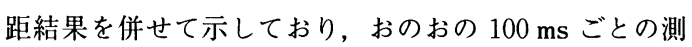
定値を $10 \mathrm{~s}$ にわたってプロットした. 炉底対象時の標 準偏差は $4 \mathrm{~mm}$ と十分小さいが, 溶銑対象時の標準偏差 $\sigma_{m v}$ は $60 \mathrm{~mm}$ と大きい. $\sigma_{m v}$ には湯面レベル変動の標準 偏差 $\sigma_{v}$ も含んでいるので本レベル計自体の測定のばら つきを評価するために電極式レベル計と比較した。

Fig. 11 は, マイクロ波式と電極式レベル計の測定值 の相関を調べた結果である. 両測定值の偏差に対する標 準偏差 $\sigma_{t}$ は $94 \mathrm{~mm}$ であり,この值には, 両測定方式に 固有のばらつきと湯面変動分が含まれている.ささらに電 極式による測定值のばらつき $\sigma_{e v}$ は $87 \mathrm{~mm}$ であること を同じく実験的に確認した，マイクロ波式および電極式 の再現䛊差の標準偏差を $\sigma_{m}, \sigma_{e}$ とする. それぞれ統計 的に独立事象とみなせるので $\sigma_{m}$ は以下のように求めら れる.

$$
\sigma_{m}=\left(\sigma_{t}^{2}-\sigma_{e v}{ }^{2}\right)^{1 / 2}=36 \mathrm{~mm}
$$

同様にして $\sigma_{v}=48 \mathrm{~mm}, \sigma_{\mathrm{e}}=72 \mathrm{~mm}$ と見積もられる.

マイクロ波式の再現誤差は電極式に比べて半減するこ とが確認された．さらに，電極式の場合は 1 チャージに 1 回しか測定できないが, マイクロ波方式の場合は, $100 \mathrm{~ms}$ で 1 回の測定ができるので, 測定時間を $5 \mathrm{~s}$ と

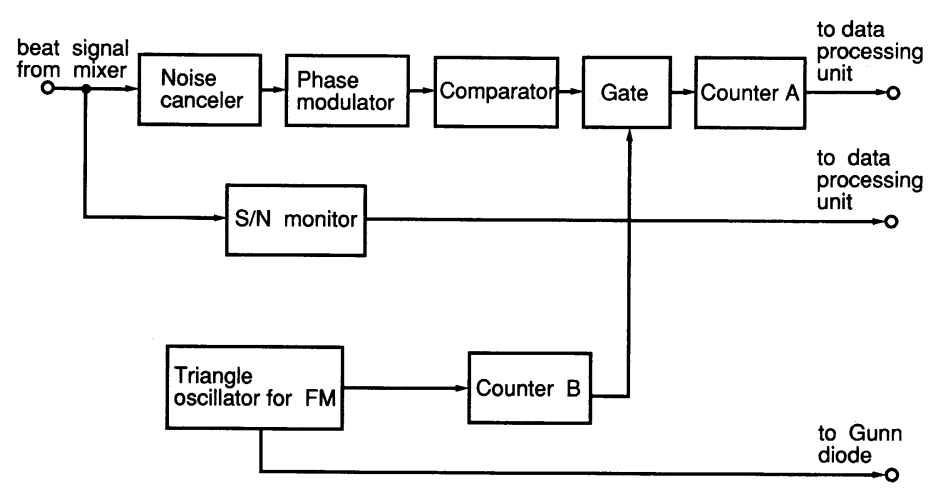

Fig. 9. Block diagram of signal processing unit. 


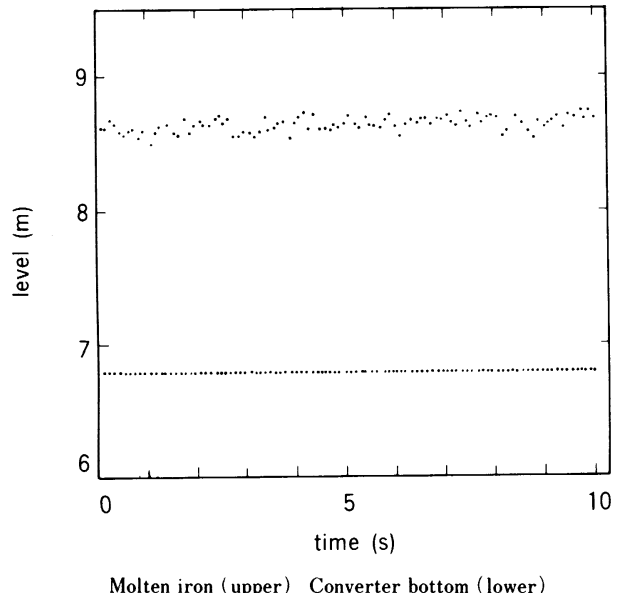

Fig. 10. Experimental results of level meter.

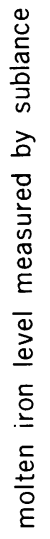

(m)

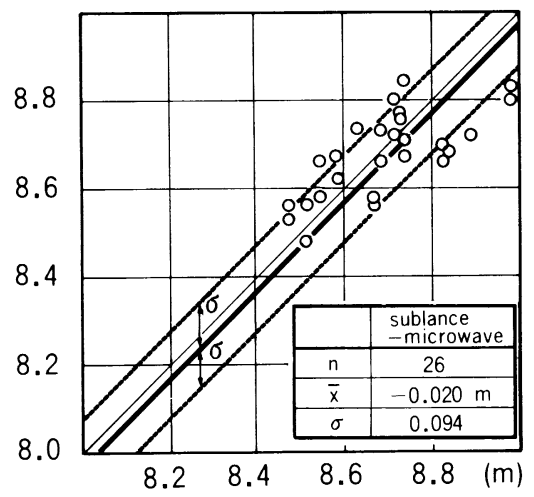

molten iron level measured by microwave

Fig. 11. Comparison of microwave measurements to conventional sublance measurements of molten iron level.

しても, 50 回の測定が可能であり, その平均を取るこ とにより $\sigma_{m}$ は $\sqrt{50}$ 分の 1 程度になることが期待で き, 再現䛊差は約 $5 \mathrm{~mm}$ となる.

測定値の絶対精度としては, 第 3 章で述べた位相変調 法の残留誤差 $14 \mathrm{~mm}$ に再現誤差 $5 \mathrm{~mm}$ が重畳したもの となるが, 目標である $20 \mathrm{~mm}$ の精度は達成できたとい える.

\section{6. マイクロ波レベル計の活用方法}

従来加古川製鉄所では，吹錬開始前に電極式レベル計 により湯面を測定していたが, 電極が消耗式のため原単 位低減の観点から各チャージごとの測定はできなかっ

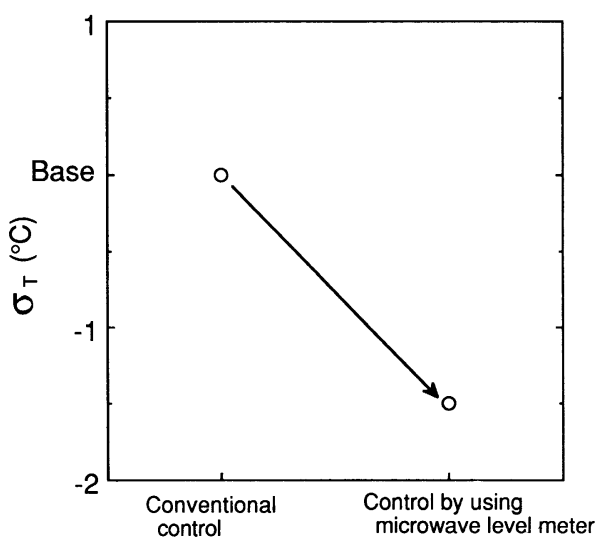

Fig. 12. Improvement of accuracy of dynamic control.

た.さらに測定精度も不十分なため, 今回全転炉ともマ イクロ波方式に切り替えた。この結果, 毎チャージ測定 が可能になるとともに, 高精度の特長を活かし実操業に 活用している．以下に実操業における活用例を示す.

\section{$6 \cdot 1$ 主ランスおよびサブランスの位置決め}

吹錬開始直前に湯面レベルを測定し，この測定値に基 づいて主ランスを位置決めすることにより, ランスと湯 面間隔を適正值に設定し, 吹止め的中率の向上を図る. さらに，吹鍊終了前にサブランスによりカーボン濃度と 温度を測定する際に, 湯面レベルの測定値に基づいてサ ブランスの溶鋼内浸漬深さを適正に設定することがで き,ダイナミック制御の精度向上が図れる.

ダイナミックモデルの温度推定精度は, 温度測定時の サブランス浸漬深さに依存するため, 加古川製鉄所では, 浸漬深さを $700 \mathrm{~mm}$ で操業管理している. マイクロ波レ ベル計を用いて浸漬深さを適正化することにより推定精 度の標準偏差 $\sigma_{T}$ は Fig. 12 に示すように, 約 1.5 度減 少した.さらに, Fig. 13 に示すように溶鋼温度および カーボン濃度の測定不良率は半減し, 吹錬時間の短縮な らびに的中率向上に顕著な効果が表れている.

\section{$6 \cdot 2$ 耐火物の僈食診断}

1 炉代にわたる，溶銑レベルの測定結果を Fig. 14 に 示す. 投入する溶銑およびスクラップ量が変動するので レベル測定值もばらついているが, 全体として右下がり の傾向を示している. 同図において, 測定値を直線回帰 すると, 溶銑レベルは 1 日あたり約 $1 \mathrm{~cm}$ 低下している ことがわかる.これは, 炉底や炉壁の耐火物が損耗した ことによるものなので, レベル低下の傾きから耐火物の 損耗量を推定することにより, 炉修時期の適正化が四れ る. 


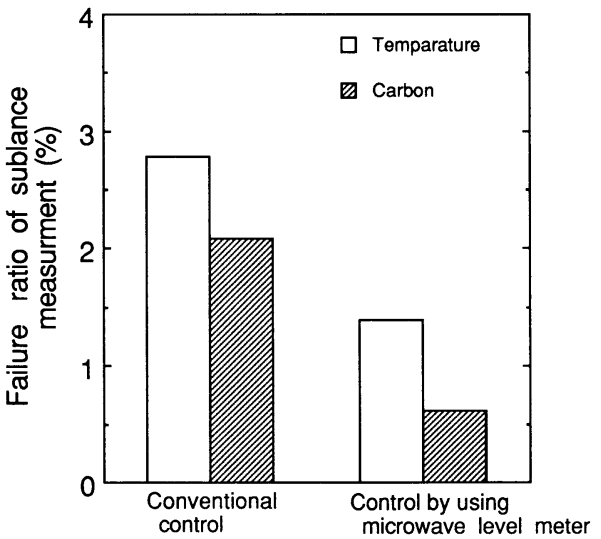

Fig. 13. Decrease of failure ratio of sublance measurement.

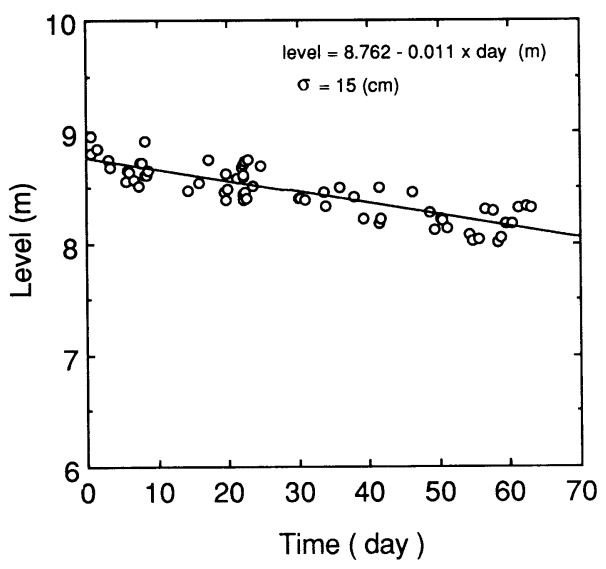

Fig. 14. Sequential change of molten iron level.

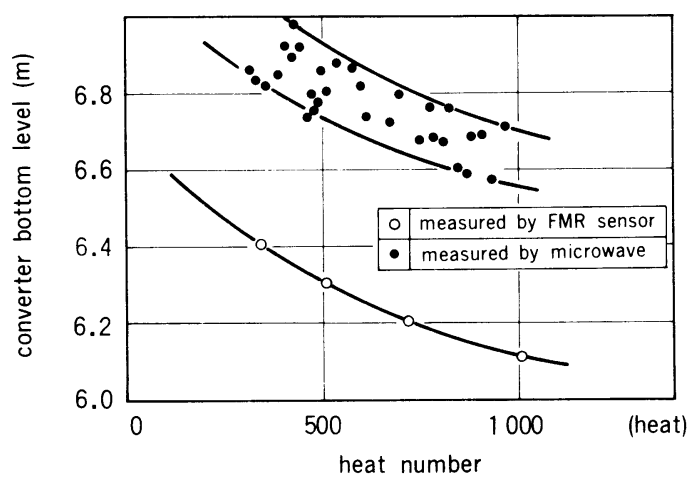

Fig. 15. Sequential change of converter bottom level measured by microwave and FMR sensor.
炉底の損耗に関しては, 出鋼後に直接測ることも可能 である. Fig. 15 は炉底のレベルを約 100 チャージにわ たって測定した結果であり，炉底に埋め込んだ Fine Multiple Resistive センサーによる測定值と比較して示 した.FMR センサーは微細な電極対を複数本, それぞ れの先端が長手方向に等間隔になるようにシース管に収 めたものであり，七ンサーが耐火物とともに損耗し，電 極対が順次導通していくことを利用して損耗量を検出す る.

マイクロ波方式の場合，炉底に残ったスラグを含めて 測定しているので, チャージごとのばらつきとオフセッ トが生じるが，1炬代にわたる損耗の傾向は一致してい る. FMR センサーは底吹き羽口に設置され局所的な損 耗量を監視している。，一方マイクロ波式の場合は, ビー ムの拡がり範用内の平均的な損耗量を検出するので両方 式の併用により，信頼性の高い炉底管理が可能である.

\section{7. 結言}

マイクロ波 FM レーダーの技術をベースとし，1)受 信信号から不要反射成分を除去して SN 比を改善する 技術 2 )位相変調法によるステップ䛊差の軽減方法 3 ) 自 動較正方法, を確立し測定レンジ $20 \mathrm{~m}$, 精度 $20 \mathrm{~mm}$ の 性能を有する転炉内溶銑レベル計を開発した。従来の電 極式レベル計のような消耗部がないので, ランニング. コストが低く，さらに短時間で信頼性の高い測定が可能 である．本レベル計の設備化にあたっては，アンテナ前 面にマイカ製のカバーを設けて窒素パージによりダスト 付着を防止するともに, マイクロ波回路は空冷を施すな ど耐環境性には注意を払った結果，1炉代にわたってメ ンテナンス・フリーで運転可能となった。

本装置は加古川製鉄所において，1989 年 7 月より自 動吹鍊の主要設備のひとつとして本格稼動している. 主 ランスおよびサブランスの位置決め用に主に活用してお ク，的中率の向上ならびに製鋼時間のばらつき低減に大 きな効果を発揮している.

\section{文献}

1 ）田中駿一: 第 3 版鉄鋼便覧第 II 巻 (日本鉄鋼協会編) (1979), p. 490 [丸善]

2 ) 川田 豊, 日下卓也, 井上憲一, 今田 紘, 宮川 裕: 計測自動制御学会論文集, 22 (1986), p. 1189

3 ) $T$. Imamura, $K$. Акimoto, $Y$. Maki and $H$. Sakimura: Proc. Ironmaking Conf., 43 (1984), p. 353

4 ) 牧野健一: レーダ技術 (1968), p. 3 [コロナ社]

5 ) $H$. P. Kalmus, J. C. Cacheris and H. A. Dropkin: I. R. E Trans-Aeronautical and Navigational Electronics, 1 (1954) 6, p. 15 